\title{
New Media in Political Marketing of Governor Election (Evidence in East Java, Indonesia)
}

\author{
Fetty Kurniawati, Pawito, Widodo Muktiyo \\ \{fefekurnia@gmail.com, pawito_palimin@staff.uns.ac.id, muktiyo@yahoo.com\}
}

Postgraduate of Communication Sciences, Sebelas Maret University

\begin{abstract}
Two decades of reforms in Indonesia led to the decentralization of leadership. Elections of district heads are a once-in-five-year political event that seizes the attention of the public, especially in the era of information because of the advanced communication technology which available today. One of the communication technologies that are widely used by leader candidates in election campaigns is the internet, both websites and social media. In the election of East Java governor in 2018, the internet has become one of the communication channels used by the pairs of governor candidates in their political campaign. Therefore, the objective of this research is to give overview of the possible differences and similarities in the implementation of political marketing which done by two pairs of candidates for East Java governor, in terms of website content and the social media which was uploaded during the registration period of prospective candidates until the voting day.
\end{abstract}

Keywords: Political Marketing, Elections, Election of East Java Governor, New Media

\section{Introduction}

The communications and information technology developed very rapidly in all countries in the world because of the presence of the Internet, including in Indonesia. Quoting from non-profit organizations engaged in the field of telematics, Indonesian Telematics Society (Mastel), the Internet started to be used in Indonesia during the 1980s which involved five universities with dial-up facility [1]. However, it did not develop well because of infrastructure problems. In 1986 - 1995, the development of the internet in Indonesia began to use radio frequency which then led to creation of mailing lists as a forum for discussion of internet drivers. In 1995, the internet had begun to enter the commercial market with the establishment of several Internet Service Providers (ISPs). In the 2000s, the internet began to develop because access was easily found in many internet cafes (warnet). The development was more rapid when a variety of mobile phones can access the internet are widely available.

The ease of access to the internet then raises various kinds of internet platforms that are widely used by the public, not only for two-way communication such as sending messages via electronic mail, but also to disseminate information to the general public through websites and social media. The appearance of Friendster, Facebook, Twitter and the latest Instagram and YouTube, make the information spread unstoppable. Indonesia is included in the top 5 rankings of country with the most number of users of popular social media in the world, which are Facebook, Instagram, Twitter and YouTube [2].

The survey by Associations of Internet Service Provider in Indonesia (APJII) in 2017 stated that as many as 143.26 million people or $54.68 \%$ of the Indonesian population are active internet users. This number has risen sharply by more than 100 million users compared to 2010 which only reached 42 million users. $57.70 \%$ are located on the island of Java with 
age range dominated by $19-34$ year-old of $49.52 \%$ [3]. This statistical data is very relevant if the internet, which later became known as new media, becomes one of the channels utilized by Indonesian politicians who fight democratically to win the contestation.

Anwar Arifin stated that political communication through the internet could reach millions of people. The mass media is always seen as having a strong influence in building opinions and knowledge for the general public [4]. Therefore, political parties and political candidates compete to introduce themselves using communication mediums which is effective but has the cheapest cost. This is where the new media internet plays an important role in the contestation process, such as what happened in the governor election in East Java in 2018, which was attended by two pairs of candidate namely Khofifah Indar Parawangsa Elestianto Dardak and Sayfullah Yusup - Puti Guntur Soekarno. The two candidates used new internet media to introduce themselves, the publication of their vision and mission, work programs, campaign agendas and self-image throughout the candidates' registration process until the voting day.

Even though they both used new media as a communication medium in a contestation, which is a necessity in today's election, there are differences between each candidate. The similarities and differences are what will be overviewed in this research based on the concept of political marketing. This research is also based on the research result by TL Towner \& DA Dulio on new media and campaigns which focused mostly on the level of presidential or congressional elections, but did not include local elections [5].

\section{Literature Review}

\subsection{Development of New Media in Political Campaigns in Indonesia}

According Lock and Haris, the political campaign is closely related to the formation of political image. The political image needs to be supported by the consistency of long-term, permanent and political activities which not only limited to just before the election. In line with the opinion of Hayes and McAllister, political campaign is the activity of positioning a party or political figure against their competitors [6]. This definition is factually practiced by parties or political figures in Indonesia in the era of direct election and information. New media in the form of the internet is the choice of parties and political figures to form and maintain their political image consistently and continuously.

The internet is considered as the beginning of new media as stated by Leah Pauline etc. The internet is supported by innovative communication tools that are increasingly sophisticated which created a new culture in the world civilization [7]. A very popular part of the internet is social media. Nowadays, social media is a very powerful tool for expressing opinions, views, and ideas and capturing aspirations to form opinion. Referring to Palmer and Koening Lewis, social media is an online application that provides facilities to interact, collaborate and sharing content [8].

The campaign through social media has become a campaign trend in countries with democratic system with direct elections ever since it proved effective in winning Barack Obama in the 2008 presidential election [9]. In Indonesia, referring to a journal written by James R Situmorang, Prabowo Subianto is a political figure who has used Facebook as a media campaign when paired with Megawati Soekarno Putri in the Presidential Election contestation. At that time, the number of accounts had friend request with Prabowo Subianto's account even exceeded the maximum capacity. However, this has no significant impact because traditional campaign media still dominate even though internet users in Indonesia have reached 30 million [10]. 
The election of governor of DKI Jakarta in 2012 became a new history for political campaigns in Indonesia. The strategy of political campaigns using new media by the pair of Joko Widodo and Basuki Tjahaya Purnama (Jokowi - Ahok) had a significant impact which made the Jokowi-Ahok pair excelled from incumbents in two rounds of voting. According to Dharma Tintri Ediraras et al, one of the campaign strategies of Jokowi-Ahok is to use the internet as a political tool. Jokowi-Ahok team used instant messaging platform such as BlackBerry Messenger to send messages, and social media platform such as Facebook, Twitter and YouTube to shape public opinion and recruit volunteers[11]. Jokowi-Ahok Social Media Volunteers (Jasmev) became a role model for parties or political figures that compete in general elections for the following year.

Internet became a medium that has a significant influence in presidential election of 2014. The two candidates competed to form an opinion and embrace the public through internet content in instant messenger applications, social media or blogs.

\subsection{Political Marketing}

Kotler (2006) stated that political marketing emphasized on transactions between voters and candidates. Oley and Iradela designed the use of a marketing mix to promote political parties. While Wring, stated that political marketing emphasized on the opinions and analysis environment [12].

O'Shaughnessy, suggested that political marketing is not a concept of "selling" political parties or candidates, but a concept that offers how a political party or a candidate can make a program related to the actual problems [13].

The process of political marketing uses the application of marketing elements commonly referred to as $4 \mathrm{P}$ (product, price, promotion, and place). The use of $4 \mathrm{P}$ techniques in politics makes marketing not only about advertising but to be more comprehensive. Political marketing concerns how candidates or political parties formulate political product, develop publicity campaigns of political programs and communication, segmentation of strategies to meet the needs of the community, to the calculation of the price of a political product [14]

The product is the policy that will be implemented which is summarized in the vision and mission. The second is the promotion; in political marketing, promise cannot be done instantly before the general elections but instead is consistently until it creates brand awareness. Third is Price; related to economic prices and psychological prices issued by candidates. Fourth is placement; related to the presence and physical reach of candidates in the community [15]

\section{Research Methodology}

This research uses a method of discourse analysis based on a political marketing research framework. Discourse analysis is a method for reviewing discourse which contained in messages of communication, both textually and contextually [16]. In more detail, this study will present and analyze the points of the political message uploaded on social media by each candidate, which then its similarities and differences would be overviewed.

The source of data of this research were from secondary data in the form of text, which were the content uploaded on the internet through both candidates' personal social media and the political parties' official social media, which work to sell candidates in the governor election. 


\section{Result And Discussion}

The election of the East Java governor was competed by two pairs of candidates, namely the Khofifah Indar Parawangsa - Elestianto Dardak and Saifullah Yusup - Puti Guntur Soekarno. The East Java province's permanent voter list (DPT) in the 2018 regional election stated that there are $30,155,719$ voters, which consists of $15,155,719$ female voters and $14,840,367$ male voters [17].

The large number of voters will be difficult to be directly reached by candidates so a media that has a wide reach but with a low cost is needed. Understanding such conditions, the two pairs of candidate both use the internet media as a channel for their political communication. This research will study about the contents uploaded by the candidate since governor candidate registration on January $8^{\text {th }}-10^{\text {th }}, 2018$ up to the voting day in June $27^{\text {th }}$, 2018.

Quoted from the news on jawapos.com, on March 20"th 2018 , the Khofifah - Emil pair registered the Facebook fanspage account under the name "Khofifah Emil Jatim", Instagram account "@khofifahemil”, line@ account "Khofifah Emil" and website domain khofifahemil.id. Meanwhile, Syaifullah - Puti pair registered three Facebook accounts with the names "Gusipul", "Putisoekarno" and "Jatimsedulur". For Instagram accounts, three were registered, namely “@gusipul_id” “@puti_soekarno” and “@jatimsedulur”. There are also 3 Twitter accounts which were reported, namely “@gusipul_id”, “@puti_soekarno” and “@jatim_sedulur” [18]. In terms of the number of registered official accounts, Saifullah Puti pair has more social media accounts because Khofifah - Emil private Instagram account was not officially registered. Moreover, the official website of jatimsedulur.com owned by the Saifullah - Puti pair was also not registered by their campaign team to the Election Comitee of East Java Province.

Instagram accounts with personal name are owned by each of the four candidates. Khofifah Indar Parawangsa has an Instagram account “@khofifah.ip” which has uploaded 58 photos and videos under the research period. Khofifah does not openly campaign in her Instagram content. However, from the upload, it shows what she wants to work on when she is elected in office. Khofifah performed her campaign slogan "Collaborative Work for East Java" through the photos and videos which she uploaded. Her closeness with various groups, from the Islamic organizations which raised her, the community of young people, to her presence at the opening ceremony of a chinatown, showed that Khofifah was a figure who could work. Photos and videos uploaded by Khofifah are not much different from what she uploaded when she yet became a candidate. Her photo with farmers, fishermen and various SME actors in East Java shows her support for local wisdom-based economic source. Policy products which offered by Khofifah clearly implied in her Instagram posts, with proper placement in accordance with the needs of prospective voters from Madura, to the west-end of East Java. Economic price and psychology was not too expensive because Khofifah has uploaded consistently as part of her promotion in reaching the brand awareness of potential voters.

His partner, Elestianto Dardak or better known by the name Emil Dardak, also have an Instagram account with the name "@emildardak". Although it is not yet a verified account with a blue checkmark, this account indeed belongs to Emil Dardak. In the same time period, Emil Dardak has upload 98 photos and videos in his Instagram account. Just like Khofifah, Emil Dardak marketed his political products through photos and activities quotations for explanation. His upload was quite interesting but it seemed to not sell immediately. Emil Dardak is very close to the activities of young people in East Java, although there are also many upload about his presence in religious and social activities. As an 
attraction for millennial voters, Emil Dardak also shows family harmony with his wife, who is a national celebrity. This is the proper product opportunity with unforced psychological costs.

Meanwhile, Instagram account “@gusipul” has uploaded 301 photos and videos in the same period, which dominantly contain his identity as a citizen of Nahdlatul Ulama. His closeness to a variety of religious leaders from various regions of East Java is shown in his Instagram uploads. In addition, Saifullah also clearly uploaded several photos and videos that contained his advantages as a candidate, his views on various problems in East Java, the infographics of work program which to be carried out, as well as photos with his family. The 'Jatim Sedulur' campaign slogan can be seen from various uploads containing social activities and open campaigns carried out by the Saifullah - Puti pair which is always crowded with many people.

Meanwhile, Instagram account “@puti_soekarno” has most number of upload compared to other three candidates, with 497 upload. Puti's account also looks very professional as a campaign media because it contains many infographics and video of priority programs. Puti also showed her identity as the granddaughter of Soekarno and her closeness with many influential figures in Indonesia ranging from many East Javanese leaders, party chairmen who supported her, namely Megawati Soekarno Putri to president Joko Widodo. Figure 1 shown Puti portrays herself as a young leader who understands the needs of millennials with her various visits in the creative industries and entrepreneurial events carried out by East Javanese youth.

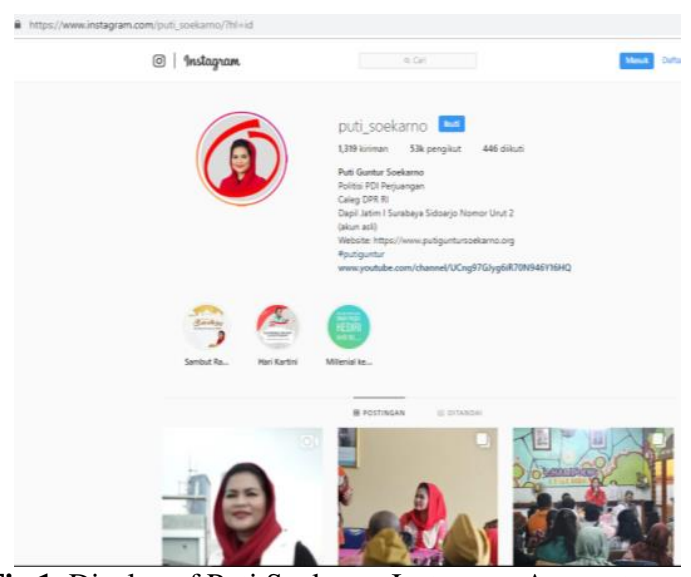

Fig 1. Display of Puti Soekarno Instagram Account

The number of likes on each of the candidate uploads is relatively the same; between 1500 - 5000 likes. But @emildardak account has the most number of average likes with at least 3000 likes.

Figure 2 shown website of Khofifahemil.id and jatimsedulur.com are basically the same, which is about the profiles of each candidate, the vision and mission program which is sold to the public, news about candidates, contacts to give advice and input and also forms to join in volunteering. When opening the website, the main page contains a photo of the candidate printed on the ballot, so that those who open it immediately understand that the website is intended as a campaign media. 


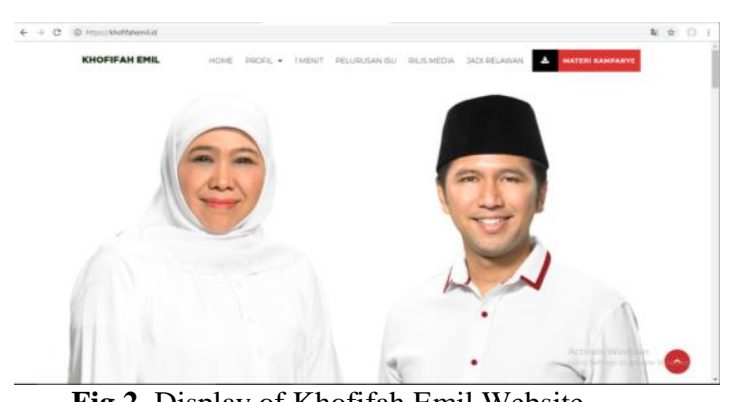

Fig 2. Display of Khofifah Emil Website

The khofifahemil facebook page (https://www.facebook.com/KhofifahdanEmil/ ), which uploaded its last content on June $26^{\text {th }}, 2018$, has 101,000 followers. Judging from the uploaded contents, this Facebook page looks professional and is managed by a team. This page contains the campaign activities, the work program and the news from mass media about Khofifah - Emil. This is different from Instagram uploads which looks more personal.

Morover, the facebook page "@gusipul_id" has a total of 219,000 followers, and "@puti_soekarno" has 102,000 followers. However, the "jatim_sedulur" page only has 5200 followers. Just like the Khofifah-Emil page, Saifullah-Puti's Facebook page also looks like it was managed by a team that looks professional. The content is also almost the same; it contains mass media coverage, work programs and campaign activities which were carried out.

The Twitter account of Khofifah under the name "@khofifahIP”, even though it has 297,000 followers, is not very actively used in the campaign. No more than 50 upload in the campaign period which only contained greetings on holidays and negative campaign confirmation about labor issues in Trenggalek. "@EmilDardak" Twitter account which has 11,500 followers is also not fully utilized for the campaign. No more than 20 upload between the registration periods until the voting period. The upload was only contains replies to questions or complaints that was delivered to him. "@puti_soekarno" Twitter account which only has 2900 followers and "@gusipul_id” account which has 6500 followers is also not used optimally as campaign media. It only contains a few replies to accounts who gave question and for sharing news links.

The explanation shows that all candidates in the East Java 2018 governor were using new media such as the internet to communicate with voters. In the uploaded text, candidates use the principle of marketing based on political marketing, namely alignment of political beliefs with promises of policy, election activities, and campaign activities. But if it is studied using the marketing principle, there are several differences, such as mentioned in table 1.

Table 1. Comparison Of Component in Political Marketing

\begin{tabular}{|l|l|l|}
\hline Component & \multicolumn{1}{|c|}{ Khofifah - Emil } & \multicolumn{1}{|c|}{ Saifullah - Puti } \\
\cline { 2 - 4 } & $\begin{array}{l}\text { Although the vision and mission is } \\
\text { written clearly in the website, the } \\
\text { pair does not explicitly seem to } \\
\text { conduct a campaign in their social } \\
\text { media. }\end{array}$ & $\begin{array}{l}\text { The pair wrote down their vision and } \\
\text { mission and elaborated priority work } \\
\text { programs offered to prospective voters } \\
\text { clearly and in detail in the form of } \\
\text { videos and infographics. }\end{array}$ \\
\hline Promotion & $\begin{array}{l}\text { The brand awareness gained by this } \\
\text { pair is higher, as shown by the } \\
\text { number of likes and comments in }\end{array}$ & $\begin{array}{l}\text { Not all Saifullah - Puti uploads received } \\
\text { followers. Lots of uploads from this }\end{array}$ \\
\hline
\end{tabular}




\begin{tabular}{|c|c|c|}
\hline & each upload on social media. & couple only get likes below 500 . \\
\hline Price & $\begin{array}{l}\text { Khofifah - emil looks very natural } \\
\text { when approaching } \\
\text { voters. Psychologically, Khofifah } \\
\text { does not seem that they are } \\
\text { forced to be down-to-earth, so does } \\
\text { Emil who does not look forced to } \\
\text { looks millennial. }\end{array}$ & $\begin{array}{l}\text { Saifullah, as a former deputy governor of } \\
\text { East Java, seemed to be able to blend in } \\
\text { with various groups. In his social media } \\
\text { uploads, he seemed eager to show his } \\
\text { religious side. Likewise with Puti, who } \\
\text { wanted to be seen as a religious grandson } \\
\text { of Soekarno. The price is heavy because } \\
\text { Puti is not well known in East Java }\end{array}$ \\
\hline Placement & $\begin{array}{l}\text { This pair divides the segment to } \\
\text { visit according to their track record. }\end{array}$ & $\begin{array}{l}\text { This pair divides the segment to visit } \\
\text { according to their track record. }\end{array}$ \\
\hline
\end{tabular}

\section{Conclusion}

In political contestation, candidates or political parties can convey all their potential as political marketing. Many tools of marketing politic emphasis on understanding the basis of marketing to be successful in long term. Political marketing in the digital era is facilitated by the development of internet technology (new media) which results in the relocation of communication channels in the form of websites and social media that allows candidates or political parties to reach the public directly and intensely. Two pairs of candidates in the East Java gubernatorial election used this new media in the process of their political campaign with the different way. The results of the analysis of the uploads displayed and the results of the vote at the election stage indicate that natural and consistent uploads can attract public sympathy as the Khofifah-Emil pair did.

\section{References}

[1] Admin, "Sejarah Perkembangan Internet di Indonesia" Mastel Indonesia https://mastel.id/sejarah-perkembangan-internet-di-indonesia/ [diakses pada 10 September 2018]

[2] T. Kurnia, "5 Negara dengan Jumlah Pengguna Media Sosial Terbanyak, Indonesia Berapa?", Liputan 6 (Online), https://www.liputan6.com/tekno/read/3481323/5-negaradengan-jumlah-pengguna-media-sosial-terbanyak-indonesia-berapa [diakses pada 10 September 2018]

[3] Admin, "Survei 2017" Asosiasi Penyelenggara Jasa Internet Indonesia, https://apjii.or.id/survei2017 [diakses pada 10 September 2018]

[4] A. Arifin, Komunikasi Politik, Filsafat - Paradigma - Teori - Tujuan - Strategi dan Komunikasi Politik di Indonesia. Graha Ilmu : Yogyakarta, 2011.

[5] T.L Towner\& D.A. Dulio, "New Media and Political Marketing in the United States : 2012 and Beyond“, Journal of Political Marketing, 11:1-2. 95-119, November 2012.

[6] Firmanzah, "Marketing Politik - Antara Pemahaman dan Realitas", Jakarta : Yayasan Pustaka Obor Indonesia, 2012.

[7] L.P. Macfadieyn etc. "Communicating Across Cultures in Cyberspace: A Bibliographical Review of Intercultural Communication Online", Munster : LIT Verlag, 2004.

[8] A. Palmer \& Koenig - Lewis, "An experimental, social network-based approach to direct marketing", Direct Marketing : An International Jounal, 3(3), 162-176, 2009.

[9] G. Grow \& J. Ward, "The Role of authenticity in electoral campaigns". First Monday Peer Review Journal, Volume 18 - Number 4, 1 April 2013. 
[10] J.R. Simutorang, "Pemanfaatan Internet Sebagai New media Dalam Bidang Politik, Bisnis, Pendidikan Dan Sosial Budaya. Jurnal Administrasi Bisnis, Vol * No. 1 Hal 73 87, (ISSN:0216-1249) Center for Bussines Studies, FISIP - Unpar, 2012.

[11] Ediraras, Dharma Tintri, dkk. "Political Marketing Strategy of Jakarta Governor Election In the 2012s“, Proceddia Social And Behavioral Sciences, Vol 81 page 584 588, 2013.

[12] A. Sugiono, "Strategic Political Marketing "Yogyakarta : Penerbit Ombak, 2013.

[13-14] Firmanzah. "Marketing Politik - Antara Pemahaman dan Realitas " Jakarta. Yayasan Pustaka Obor Indonesia, 2008.

[15] A. Sugiono, Strategic Political Marketing. Yogyakarta : Penerbit Ombak, 2013.

[16] Pawito. "Penelitian Komunikasi Kualitatif", Yogyakarta : LkiS Pelangi Aksara, 2008.

[17] M. Ardiansyah, "Penetapan DPT Pilgub Jatim selesai, KPU siap cetak surat suara", https://www.merdeka.com/politik/penetapan-dpt-pilgub-jatim-selesai-kpu-siap-cetaksurat-suara.html, Merdeka Online [diakses pada 12 September 2018]

[18] Admin, "Ini Akun Media Sosial Cagub-Cawagub Jatim", Jawa Pos Online, https://www.jawapos.com/nasional/pemilihan/20/03/2018/ini-akun-media-sosial-cagubcawagub-jatim 